\title{
Clinical Features of First-episode Psychoses During the COVID-19 Pandemic
}

\author{
Клиническая картина манифестных психотических состояний \\ в период пандемии COVID-19 \\ DOI:10.17816/CP85
}

Original article

Vladimir A. Zyablov, Mikhail A. Gusev, Vasilyi S. Chizhikov

Mental health clinic No.1 named after N.A. Alexeev,

Moscow, Russia

The article can be used under the CC BY-NC-ND 4.0 license

(c) Authors, 2021

\section{Владимир А. Зяблов, Михаил А. Гусев, Василий С. Чижиков}

ГБУз «Психиатрическая клиническая больница №1 им. Н. А. Алексеева Департамента здравоохранения города Москвы», Москва, Россия

Личензия CC BY-NC-ND 4.0

(с) Коллектив авторов, 2021

\section{ABSTRACT}

INTRODUCTION: The pandemic of the new coronavirus infection has become one of the most significant global social shocks in the past decade. It influenced the lifestyle of many people, including those with mental disorders.

AIM: To compare the psychopathological structure of psychotic states in young patients (up to 40 years old) with firstepisode psychosis before the COVID-19 pandemic and during the COVID-19 pandemic.

METHODS: The research was conducted at the First psychotic episode clinic of the Mental-health clinic No. 1 n.a. N.A. Alexeev, Moscow, Russia. In total, 66 patients were enrolled, who met the inclusion criteria: first-in-life admission to a mental healthcare unit that occurred during the spring of 2019 (control group) or spring 2020 (experimental group), diagnosis on admission that belonged to the group "Acute and transient psychotic disorders" (F23.XX) of ICD10. Patients with a disability or concurrent somatic or neurologic conditions were excluded from the study. Assessment of clinical and psychopathological characteristics with the allocation of the leading syndrome within the psychotic state, psychometric assessment according to the PANSS scale was carried out, the above indicators were compared between the experimental and control group.

RESULTS: We observed statistically insignificant increase in the rates of affective and catatonic subtypes of psychoses, a decrease in the rate of the delusional subtype of paranoid syndrome. PANSS scores differed significantly for different clinical subtypes of psychoses, although the differences between the experimental and control groups showed no statistical significance. Additionally, in spring 2020, a considerable decrease in the total number of hospitalizations was revealed.

CONCLUSIONS: The differences in the clinical and psychopathological structure of psychotic states revealed during the COVID-19 pandemic were statistically insignificant. Additional results of the study may indicate a decrease in the availability of mental healthcare for patients with psychoses, which requires further investigation. 


\section{АННОТАЦИЯ}

АКТУАЛЬНОСТЬ: Пандемия новой коронавирусной инфекции стала одним из социально значимых потрясений всемирного масштаба в последнее десятилетие. Она оказала существенное влияние на уклад жизни многих людей, в том числе на больных с психическими расстройствами.

ЦЕЛЬ: Сравнить психопатологическую структуру манифестных психотических состояний у пациентов молодого возраста (до 40 лет) до пандемии COVID-19 и во время пандемии COVID-19.

МАТЕРИАЛ И МЕТОДЫ: Работа ВЫПолНена в КлИнИке первого псИХотИческого эпИзода, подразделениИ ГБУЗ «ПКБ №1 им. Н.А. Алексеева» ДЗМ. Всего в исследование включены 66 пациентов, отвечавших критериям включения - первичная госпитализация в ПКБ№1 весной 2019 (группа сравнения - 45 пациентов) или 2020 (основная группа - 21 пациент) года, диагноз из рубрики F23, отсутствие инвалидности, сопутствующей соматической или неврологической патологии, которая затрудняла обследование или требовала дополнительных лекарственных назначений. Проведена оценка клинико-психопатологических характеристик с выделением ведущего синдрома в рамках психотического состояния, психометрическая оценка по шкале PANSS, вышеуказанные показатели сопоставлены между основной группой и группой сравнения.

РЕЗУЛЬТАТЫ: Выявлено статистически незначимое увеличение доли аффективно-бредовых и кататонобредовых состояний, а также уменьшение доли параноидных состояний за счет бредового их варианта. Результаты психометрической оценки по PANSS достоверно различались между пациентами с разными клинико-психопатологическими вариантами психозов, однако значимых различий между основной группой и группой сравнения обнаружено не было. Дополнительно было обнаружено уменьшение общего количества госпитализаций весной 2020 года.

Выводы: Выявленные в ходе исследования различия клинико-психопатологической структуры манифестных психотических состояний в период пандемии COVID-19 не продемонстрировали статистической значимости. Побочные результаты исследования могут указывать на изменение доступности психиатрической помощи для пациентов с манифестными психотическими состояниями, что требует дальнейшего изучения.

Keywords: COVID-19; psychosis; first-episode psychosis; acute and transient psychotic disorders; PANSS Ключевые слова: COVID-19; психоз; первый психотический эпизод; острые и преходящие психотические расстройства; PANSS

\section{INTRODUCTION}

The pandemic of the new coronavirus infection is undoubtedly one of the most significant shocks of recent decades. Besides an immediate "biological" impact on the human body, the COVID-19 pandemic and widespread antiepidemic measures which have been introduced have fundamentally affected the mode of life of many people, including those suffering from mental disorders. ${ }^{1,2}$ Large-scale quarantine measures ("lockdown" or "self-isolation") have especially affected social contacts and lifestyle habits, that together with economic instability and contradictory information about the pandemic increased psychological distress. ${ }^{3-5}$ Thus, a global psychotraumatic situation has been formed, which affects human mental well-being. ${ }^{6,7}$ During the pandemic period, an increase in the incidence of reactive mental disorders has been noticed, including those on the psychotic register. ${ }^{8}$ Besides the influence on the population as a whole, some authors point to the possibility of the infection negatively influencing patients with a history of mental disorders ${ }^{9}$ and, moreover, exacerbation

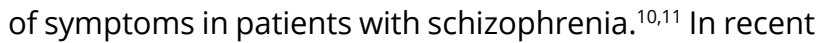
studies, there are sporadic indications of a change in the clinical representation of psychiatric disorders under the influence of the coronavirus infection or antiepidemic measures. ${ }^{12}$ Despite achievements in recent decades in the sphere of studying psychic disorders as a whole and their clinical peculiarities, various questions 
concerning diagnostics and the clinical picture of manifest psychotic states during large-scale social shocks remain unsolved. ${ }^{13}$ Little is known about the association between the COVID-19 pandemic and manifest psychotic states. A number of clinical cases of acute psychoses were described in patients who have experienced a new coronavirus infection ${ }^{14-16}$ or psychoses whose development could be associated with the psychological impact of an unfavourable epidemic situation. ${ }^{17,18}$ Special attention is attracted towards dangerous and potentially lethal cases of catatonia ${ }^{19}$, associated with disease itself ${ }^{20,21}$ as well as its psychosocial impact. ${ }^{22,23}$ Meanwhile, Russian researchers have mainly studied various aspects of the pandemic impact on the incidence of nonpsychotic mental disorders. ${ }^{24-26}$ Thus, there is a need to consider fundamentally important questions concerning the prognosis and psychopathological characteristics of psychoses manifested during the coronavirus pandemic.

The goal of this research was to compare the psychopathological structure and syndrome severity of manifest psychotic states in young patients (under 40 years old) before the COVID-19 pandemic and during the COVID-19 pandemic.

Hypothesis. The psychopathological structure of manifest psychotic states and syndrome severity changed during the COVID-19 pandemic. These changes can be attributed to an increase in the incidence rate and severity of catatonic syndrome.

\section{METHODS}

The research was carried out in the First psychotic episode clinic of the Mental-health clinic No. 1 n.a. N.A. Alexeev of Moscow Healthcare Department.

The inclusion criteria were as follows: diagnosis F23 according to ICD-10; hospitalization between March 1 and May 312019 or 2020; absence of disability or comorbid physical or neurological pathology that would make medical examination difficult or would require additional drug prescriptions. The choice of the enrolment time period in 2020 for experimental group was determined by introduction of the most radical antiepidemic measures (The Decree of the President of the Russian Federation "On Measures to Ensure Sanitary and Epidemiological Welfare of the Population on the Territory of the Russian
Federation Owing to the Spread of a New Coronavirus Infection (COVID-19) of April 2, 2020"), which, to our understanding, could have had the greatest impact on the mental state of our patients. The control group included patients hospitalized in the clinic in the same period of the previous year.

The research sample comprised 66 patients ( 27 men and 39 women), who had received in-patient treatment due to manifest psychotic states in spring 2019 or 2020. The research participants were divided into two groups: the experimental group (2020, $n=21$ ) and the control group $(2019, n=45)$. All participants in the experimental group were COVID negative at the time of experiment. Two patients had a confirmed diagnosis of COVID-19 infection 4 to 8 weeks prior to the experiment.

A comparison of the main sociodemographic indices (sex, average age, education level and employment status) was performed to evaluate the comparability of the groups according to social parameters. Evaluation of the mental state was carried out using a clinical psychopathological method, singling out the dominating syndrome. Patients were divided into subgroups according to the leading syndrome type.

The Russian version of PANSS (Positive and Negative Syndrome Scale) 27 was used to evaluate the severity of mental symptoms at the point of hospital admission. Our psychometric examination included an additional evaluation using the "catatonia subscale" (N1-4, N6, G1-3, G5-7, G11, G13, G15 and G16 point scores), ${ }^{28,29}$ conditionally labelled by the letter " $\mathrm{C}$ ", with a maximum total score 105.

The statistical analysis of the received frequency data was performed using Pearson chi-squared $\chi^{2}$ test. The Fisher's angular transformation $\varphi$ was used in cases where application of $\chi^{2}$ test was impossible. Student's t-criterion was used to compare the average duration of the initial psychosis phase and PANSS scores in the sample groups. The mean (M) was used to evaluate the central tendency, and data scattering was used to evaluate the standard deviation (SD). 30 Value of $p \leq 0.05$ was accepted as statistically significant.

The research was conducted in accordance with the Declaration of Helsinki regarding issues of medical ethics, and the participants' rights, interests and personal dignity were protected at all times. All the patients examined gave their informed consent prior to participating in the research. 
Table 1. Clinical and sociodemographic characteristics of patients

\begin{tabular}{|c|c|c|c|c|c|}
\hline \multirow{2}{*}{ Parameter } & \multicolumn{2}{|c|}{$2019(n=45)$} & \multicolumn{2}{|c|}{$2020(n=21)$} & \multirow{2}{*}{ Statistical significance indices } \\
\hline & $\mathbf{n}$ & $\%$ & $\mathbf{n}$ & $\%$ & \\
\hline Women & 25 & 55.6 & 14 & 66.6 & $\chi^{2}=0.706 ; d f=1 ; p=0.403$ \\
\hline Men & 20 & 44.4 & 7 & 33.3 & $\chi^{2}=0.719 ; d f=1 ; p=0.396$ \\
\hline \multicolumn{6}{|c|}{ Education level at the time of the medical examination } \\
\hline Secondary education & 5 & 11.1 & 6 & 28.6 & $\varphi=1.7 ; p<0.05$ \\
\hline Specialized secondary education & 6 & 13.3 & 2 & 9.5 & $\varphi=0.4 ; p>0.05$ \\
\hline Incomplete higher education & 6 & 13.3 & 2 & 9.5 & $\varphi=0.4 ; p>0.05$ \\
\hline Higher education & 28 & 62.3 & 11 & 52.4 & $\varphi=0.7 ; p>0.05$ \\
\hline \multicolumn{6}{|c|}{ Employment status at the time of the medical examination } \\
\hline College student & 3 & 6.7 & 1 & 4.8 & $\varphi=0.3 ; p>0.05$ \\
\hline University student & 4 & 8.9 & 1 & 4.8 & $\varphi=0.6 ; p>0.05$ \\
\hline Specialist (skilled job) & 3 & 6.7 & 1 & 4.8 & $\varphi=0.3 ; p>0.05$ \\
\hline Unskilled labour & 7 & 15.5 & 2 & 9.6 & $\varphi=0.7 ; p>0.05$ \\
\hline Unemployed & 28 & 62.2 & 16 & 76.2 & $\varphi=1.2 ; p>0.05$ \\
\hline
\end{tabular}

\section{RESULTS}

\section{Sociodemographic characteristics}

The experimental group (2020) consisted of 14 women $(66.6 \%)$ and 7 men (33.3\%), and their average age was $28.2 \pm 7.3$ years. The control group (2019) comprised 25 women (55.6\%) and 20 men (44.4\%), with an average age of $27.3 \pm 5.6$ years. The groups of patients were comparable in terms of sex and sociodemographic characteristics at the time of medical examination (Table 1).

\section{PSYCHOPATHOLOGICAL CHARACTERISTICS}

The duration of the initial phase of the manifest psychotic state (the period immediately preceding development of psychosis, during which the nonpsychotic disorders or transitory psychotic symptoms were observed) varied significantly: $4.8 \pm 4.6$ weeks in the experimental group versus $14.6 \pm 11.1$ weeks in the control group ( $p=0.03)$.

Three variants of manifest psychotic syndromes were determined on the basis of the prevailing psychopathological symptomatology: affectivedelusional, paranoid and catatonic, each of them was additionally divided into subvariants.

Affective-delusional syndrome $(n=25)$ was characterized by prevalence of the changed affect in combination with acute sensory delusions, in the absence of delusions of perception and psychic automatisms. This variant of psychotic states was represented by manic-delusional, depressive-delusional and mixed affective-delusional states depending on the dominating pole of affect.

Manic-delusional states $(n=7)$ were accompanied by the dominating elevated mood, often with irritability, that corresponded with delusions of grandeur, special abilities and messianism, always followed by ideas of persecution. The structure of the depressivedelusional states $(n=3)$ was represented by an anxietydepressive affect with delusional ideas of guilt, sinfulness, contagion and apprehension of imminent, inevitable punishment.

The mixed affective-delusional states $(n=15)$ were characterised by unstable affect, with elements of symptoms of each affective pole, episodes of intensive panic, mental disorganization, confusion, staging phenomena and delusions of special significance.

Paranoid syndrome ( $n=22)$. The leading psychopathological symptoms were acute hallucinations or psychic automatisms together with persecutory delusions.

The hallucinatory variant $(n=9)$ was characterized by a high intensity of hallucinations, which designated the delusional content and patients' behavior.

In the delusional variant $(n=13)$, in the absence of hallucinations or their low intensity, the condition 
was defined by pronounced mental automatisms (usually represented not only by ideational but also by motor or sensory types), as well as by delusions of influence or capture syndrome.

Catatonic syndrome $(n=19)$. The psychotic states in this group were united by a prevalence of catatonic symptomatology (psychomotor agitation, stupor, catalepsy, mutism, negativism, speech and motor stereotypies, echolalia or echopraxia).

In catatonic-delusional states $(n=15)$, the catatonic symptomatology was accompanied by hallucinations, mental automatisms, delusions of persecution or of influence.

States exclusively represented by catatonic symptomatology were rare $(n=4)$. Such conditions corresponded to the definition of "lucid" catatonia and were characterized by a predominance of hypokinetic motor disorders in the form of stupor or substupor.

The prevalence of patients' leading psychopathological syndromes is represented in Table 2.

The prevalence of affective-delusional, paranoid and catatonic syndromes did not differ significantly in 2019 and 2020.

\section{PSYCHOMETRIC EVALUATION USING PANSS}

Statistically significant differences were found between clinical subgroups in PANSS total scores $(p=0.04)$, and in pair-wise comparison of $C$ subscale score between
Table 2. Prevalence of psychotic syndrome types in 2019 and 2020

\begin{tabular}{|l|l|l|l|l|l|}
\hline \multirow{2}{*}{ Syndrome } & \multicolumn{2}{|l|}{$\begin{array}{l}\mathbf{2 0 1 9} \\
(n=45)\end{array}$} & \multicolumn{2}{l|}{$\begin{array}{l}\text { 2020 } \\
(n=21)\end{array}$} & \multicolumn{2}{l|}{$\begin{array}{l}\text { Statistical } \\
\text { significance } \\
\text { indices }\end{array}$} \\
\cline { 2 - 6 } & $\mathbf{n}$ & $\mathbf{\%}$ & $\mathbf{n}$ & $\mathbf{\%}$ & \\
\hline $\begin{array}{l}\text { Affective- } \\
\text { delusional } \\
\text { syndrome }\end{array}$ & 16 & 35.5 & 9 & 42.9 & $\begin{array}{l}\chi^{2}=0.328 ; \\
\mathrm{df}=1 ; \mathrm{p}=0.567\end{array}$ \\
\hline $\begin{array}{l}\text { Paranoid } \\
\text { syndrome }\end{array}$ & 16 & 35.5 & 6 & 28.6 & $\begin{array}{l}\chi^{2}=0.302 ; \\
\mathrm{df}=1 ; \mathrm{p}=0.583\end{array}$ \\
\hline $\begin{array}{l}\text { Catatonic } \\
\text { syndrome }\end{array}$ & 13 & 29 & 6 & 28.6 & $\begin{array}{l}\chi^{2}=0.001 ; \\
\mathrm{df}=1 ; \mathrm{p}=0.9736\end{array}$ \\
\hline
\end{tabular}

the catatonic subgroup and affective-delusional and paranoid subgroups $(p=0.02)$. Statistically significant differences in psychopathological structure of psychosis were not found between the experimental group and the control group (Table 3).

\section{DISCUSSION}

Despite our hypothesis that COVID-19 pandemic from the very beginning could have influenced the mental state of the patients with psychotic spectrum disorders, we did not manage to find any statistically significant differences between experimental and control groups.

Patients with the affective-delusional syndrome demonstrated a higher score on the PANSS P scale (2019: 26; 2020: 24.6) than on the N scale (2019: 23.4; 2020: 23.8) in both groups. The catatonia scale score was moderately

Table 3. PANSS scores $(M \pm S D)$ in the clinical subgroups according to the leading syndrome type

\begin{tabular}{|c|c|c|c|c|c|c|}
\hline \multirow{3}{*}{$\begin{array}{l}\text { PANSS } \\
\text { Scale }\end{array}$} & \multicolumn{6}{|c|}{ Leading psychopathological syndrome } \\
\hline & \multicolumn{2}{|c|}{ Affective-delusional syndrome } & \multicolumn{2}{|c|}{ Paranoid syndrome } & \multicolumn{2}{|c|}{ Catatonic syndrome } \\
\hline & $\begin{array}{l}2019 \\
(n=16)\end{array}$ & $\begin{array}{l}2020 \\
(n=9)\end{array}$ & $\begin{array}{l}2019 \\
(n=16)\end{array}$ & $\begin{array}{l}2020 \\
(n=6)\end{array}$ & $\begin{array}{l}2019 \\
(n=13)\end{array}$ & $\begin{array}{l}2020 \\
(n=6)\end{array}$ \\
\hline $\mathrm{P}$ & $26 \pm 4.8$ & $24.6 \pm 6.3$ & $24.3 \pm 5.2$ & $24.2 \pm 3.6$ & $26.8 \pm 6$ & $28 \pm 5.3$ \\
\hline N & $23.4 \pm 6.1$ & $23.8 \pm 4$ & $22.9 \pm 5.2$ & $24.3 \pm 6$ & $29 \pm 7.4$ & $33.8 \pm 11.5$ \\
\hline G & $49.1 \pm 8.8$ & $49.2 \pm 6.1$ & $45.1 \pm 7.3$ & $47.3 \pm 7.9$ & $60.5 \pm 12.7$ & $64.5 \pm 13.5$ \\
\hline$C$ & $41.7 \pm 9.5$ & $42.2 \pm 9.5$ & $40.1 \pm 6.2$ & $42.5 \pm 8.5$ & $53.8 \pm 13.1$ & $57 \pm 14.4$ \\
\hline$\Sigma$ & $107.4 \pm 16$ & $105 \pm 12.8$ & $99.8 \pm 18.1$ & $102.6 \pm 18.2$ & $126.1 \pm 27.1$ & $135.2 \pm 31.3$ \\
\hline
\end{tabular}

Footnote. $P$ is the positive symptomatology scale; $N$ is the negative symptomatology scale; $G$ is the general psychopathological symptomatology scale; $C$ is the catatonia scale; $\sum$ is the total score. 
high (41.9 and 42.2 in 2019 and 2020, respectively), the total PANSS score was intermediate, compared to other groups (2019: 107.4; 2020: 105).

Patients with paranoid syndrome had lower total PANSS scores (2019: 99.8; 2020: 102.6) and lower scores on P scale (2019: 24.3; 2020: 24.2), with slightly higher scores on the $\mathrm{N}$ scale (2019: 22.9; 2020: 24.3), while the scores on the catatonia subscale did not differ from those of the affective-delusional syndrome subgroup (2019: 40.0; 2020: 42.5).

The most severe psychopathological disorders were observed in patients with catatonic syndrome according to PANSS total score (2019: 126.1; 2020: 135.2). Scores on the $P$ scale were slightly higher than in other groups (2019: 26.8; 2020: 28), negative syndromes according to $N$ scale score were more pronounced comparing to other subgroups (2019: 29; 2020: 33.8). Higher scores were also noted on the catatonia subscale: 53.8 and 57 in 2019 and 2020, respectively.

It should be noted that a number of factors could have affected the results of the research. Firstly, verification of statistical significance was essentially limited by a small sample size. Secondly, we noticed that the total number of patients hospitalized with F23 diagnoses was significantly higher in 2019 (45 patients) than in 2020 (21 patients). This observation corresponds with data showing a decrease in the total number of hospitalizations in Mental-health Clinic No.1 named after N.A. Alexeev for the period studied (2152 hospitalizations in spring 2019; 1597 hospitalizations in spring 2020). A probable decrease in the availability of psychiatric help could influence the characteristics of the sample in 2020. Thirdly, of the examined patients, few had received a confirmed diagnosis of the COVID-19 infection, thus, in the experimental group only the psychosocial impact of the pandemic, but not the virus infection itself could have any impact on the course of psychotic disorders.

\section{CONCLUSIONS}

During the first months of the COVID-19 pandemic no difference was observed in the psychopathological structure of manifest psychotic states of in-patients. Therefore, it is necessary for further (extensive) research to be carried out to examine the impact of the COVID-19 pandemic on the manifestations of psychotic conditions.
Manuscript process:

Submitted: 28.06 .2021

Accepted: 03.08.2021

Published: 30.09 .2021

Funding: The research was carried out without support from a sponsor.

Conflict of interests: The authors declare no conflicts of interest.

Acknowledgements: The authors would like to express their gratitude to AM Levin, head of First psychotic episode clinic of the Mental-health Clinic No.1 named after N.A. Alexeev, for his valuable advice during discussion of the research results.

Authors" contribution: V.A. Zyablov - concept and design of the article; V.S. Chizhikov - reviewing publications, obtaining data for analysis; M.A. Gusev reviewing publications, obtaining data and data analysis, drawing conclusions. All authors participated equally in the discussion.

\section{Correspondence to:}

\section{Mikhail A. Gusev}

powilenski@gmail.com

\section{For citation:}

Zyablov VA, Gusev MA, Chizhikov VS. Clinical features of first-episode psychoses during the COVID-19 pandemic. Consortium Psychiatricum. 2021;2(3):27-33. DOI:10.17816/CP85

\section{References}

1. Gaebel W, Lukies R, Stricker J. COVID-19: consequences for mental health and the use of e-Mental health options. Consortium Psychiatricum. 2020;1(1):3-7. doi:10.17650/2712-7672-2020-1-1-3-7

2. Karpenko OA, Syunyakov TS, Kulygina MA, et al. Impact of COVID-19 pandemic on anxiety, depression and distress online survey results amid the pandemic in Russia. Consortium Psychiatricum. 2020;1(1):8-20. doi:10.17650/2712-7672-2020-1-1-8-20

3. Filgueiras A, Stults-Kolehmainen M. Risk Factors for Potential Mental Illness Among Brazilians in Quarantine Due To COVID-19. Psychol Rep. 2021:33294120976628. doi:10.1177/0033294120976628

4. Luo X, Estill J, Wang Q, et al. The psychological impact of quarantine on coronavirus disease 2019 (COVID-19). Psychiatry Res. 2020;291:113193. doi:10.1016/j.psychres.2020.113193 
5. Torales J, Rios-Gonzalez C, Barrios I, et al. Self-Perceived Stress During the Quarantine of COVID-19 Pandemic in Paraguay: An Exploratory Survey. Front Psychiatry. 2020;11:558691. doi:10.3389/ fpsyt.2020.558691

6. Brooks SK, Webster RK, Smith LE, et al. The psychological impact of quarantine and how to reduce it: rapid review of the evidence. Lancet. 2020;395(10227):912-920. doi:10.1016/s01406736(20)30460-8

7. Pandey D, Bansal S, Goyal S, et al. Psychological impact of mass quarantine on population during pandemics-The COVID-19 Lock-Down (COLD) study. PLoS One. 2020;15(10):e0240501. doi:10.1371/journal.pone.0240501

8. Tucker P, Czapla CS. Post-COVID stress disorder: another emerging consequence of the global pandemic. Psychiatric Times. $2021 ;(38) 1$.

9. Yang Y, Li W, Zhang Q, et al. Mental health services for older adults in China during the COVID-19 outbreak. Lancet Psychiatry. 2020;7(4):e19. doi:10.1016/s2215-0366(20)30079-1

10. Yao H, Chen J-H, Xu Y-F. Patients with mental health disorders in the COVID-19 epidemic. The Lancet Psychiatry. 2020;7(4):e21. doi:10.1016/s2215-0366(20)30090-0

11. Fischer M, Coogan AN, Faltraco F, Thome J. COVID-19 paranoia in a patient suffering from schizophrenic psychosis - a case report. Psychiatry Res. 2020;288:113001. doi:10.1016/j. psychres.2020.113001

12. Gouse BM, Spears WE, Nieves Archibald A, Montalvo C. Catatonia in a hospitalized patient with COVID-19 and proposed immunemediated mechanism. Brain Behav Immun. 2020;89:529-530. doi:10.1016/j.bbi.2020.08.007

13. Neznanov NG, Shmukler AB, Kostyuk GP, Sofronov AG. The first psychotic episode: epidemiological aspects of care provision. Article in Russian. Sotsial'naya i klinicheskaya psikhiatriya. 2018;28(3):5-11.

14. Correa-Palacio AF, Hernandez-Huerta D, Gomez-Arnau J, Loeck C, Caballero I. Affective psychosis after COVID-19 infection in a previously healthy patient: a case report. Psychiatry Res. 2020;290:113115. doi:10.1016/j.psychres.2020.113115

15. Smith CM, Komisar JR, Mourad A, Kincaid BR. COVID-19-associated brief psychotic disorder. BMJ Case Rep. 2020;13(8). doi:10.1136/ bcr-2020-236940

16. Parra A, Juanes A, Losada CP, et al. Psychotic symptoms in COVID-19 patients. A retrospective descriptive study. Psychiatry Res. 2020;291:113254. doi:10.1016/j.psychres.2020.113254

17. Huarcaya-Victoria J, Herrera D, Castillo C. Psychosis in a patient with anxiety related to COVID-19: A case report. Psychiatry Res. 2020;289:113052. doi:10.1016/j.psychres.2020.113052
18. Rentero D, Juanes A, Losada CP, et al. New-onset psychosis in COVID-19 pandemic: a case series in Madrid. Psychiatry Res. 2020;290:113097. doi:10.1016/j.psychres.2020.113097

19. Cooper JJ, Ross DA. COVID-19 Catatonia-Would We Even Know? Biol Psychiatry. 2020;88(5):e19-e21. doi:10.1016/j. biopsych.2020.07.001

20. Caan MP, Lim CT, Howard M. A Case of Catatonia in a Man With COVID-19. Psychosomatics. 2020;61(5):556-560. doi:10.1016/j. psym.2020.05.021

21. Zain SM, Muthukanagaraj P, Rahman N. Excited Catatonia - A Delayed Neuropsychiatric Complication of COVID-19 Infection. Cureus. 2021;13(3):e13891. doi:10.7759/cureus.13891

22. Sarli G, Polidori L, Lester D, Pompili M. COVID-19 related lockdown: a trigger from the pre-melancholic phase to catatonia and depression, a case report of a 59 year-old man. BMC Psychiatry. 2020;20(1):558. doi:10.1186/s12888-020-02978-2

23. Lynch A, Bastiampillai T. COVID-19 Pandemic-Induced Late-Onset Psychotic Depression With Catatonia. Prim Care Companion CNS Disord. 2021;23(1). doi:10.4088/PCC.20102827

24. Ostrovskii DI, Ivanova TI. (2020). Influence of the new coronavirus COVID-19 infection on human mental health (literature review). Article in Russian. Omskii psikhiatricheskii zhurnal. 2020;S2-1(24). doi:10.24411/2412-8805-2020-10201

25. Sorokin M, Kasyanov ED, Rukavishnikov GV, et al. Structure of anxiety associated with COVID-19 pandemic: the online survey results. Bulletin of Russian State Medical University. 2020((3)2020):70-76. doi:10.24075/brsmu.2020.030

26. Gritsenko VV, Reznik AD, Konstantinov VV, et al. Fear of Coronavirus Disease (COVID-19) and Basic Personality Beliefs. Clinical Psychology and Special Education. 2020;9(2):99-118. doi:10.17759/cpse.2020090205

27. Mosolov SN. Влияние новой коронавирусной инфекции COVID-19 на психическое здоровье человека (обзор литературы). Novyі tsvet; 2001.

28. Kay SR, Sevy S. Pyramidical Model of Schizophrenia. Schizophrenia Bulletin. 1990;16(3):537-545. doi:10.1093/schbul/16.3.537

29. Zhilyaeva TV, Sergeeva AV, Blagonravova AS, Akimova EV, Kasimova LN. Folate metabolism genetic polymorphism MTHFR 677C>T and catatonic symptoms of schizophrenia. Article in Russian. Nevrologicheskii vestnik, 2016;48:2-S:12-6. doi: 10.17816/ nb13977

30. Trushchelev SA. General issues of statistical analysis methodology: data types and algorithms selection tables, graphical visualizations. Article in Russian. Russian Journal of Psychiatry. 2014;(1):68-73. 